\title{
APPLICABILITY OF THE LEAN CONCEPT TO THE MANAGEMENT OF SMALL-SCALE MANUFACTURING ENTERPRISES IN SERBIA
}

\author{
Miloš Vorkapić, Filip Radovanović, Dragan Ćoćkalo, Dejan Đorđević
}

Preliminary communication

Lean management (LM) is a set of procedures and principles used in industrial processes for finding and eliminating useless activities. This paper presents the analysis of business practices in small-scale manufacturing enterprises in Serbia in comparison with defined LM principles. Application of LM standards to reduce waste and optimize production in SMEs in Serbia has not been investigated before, although this practice has been successfully used in neighboring countries. The importance of this approach is related to the benefits of improving business practices in SMEs in Serbia. This study shows that enterprises lack a system ensuring that the customer gets a quality product on time, the optimization of production and resources are limited, and a significant difference exists between job requirements and skills. The recommendations to improve operations include introduction of a monitoring and control system to ensure timely delivery and customer satisfaction, and introduction of various LM tools.

Keywords: lean manufacturing; manufacturing improvement; small-scale production; tools; waste

Primjena lean koncepta u upravljanju poduzećima s maloserijskom proizvodnjom u Srbiji

Prethodno priopćenje

Lean menadžment (LM) je skupina postupaka i principa koji se koriste u industrijskim procesima za pronalaženje i eliminiranje nepotrebinh aktivnosti. Ovaj rad predstavlja analizu poslovne prakse u preduzećima s maloserijskom proizvodnjom u Srbiji u poređenju s definiranim principima LM-a. Primjena LM standarda za smanjenje otpada i optimizaciju proizvodnje u MSP u Srbiji nije istražena ranije, iako je ovaj postupak uspješno korišten u susjednim zemljama. Značaj ovakvog pristupa u vezi je s prednostima poboljšanja poslovnih aktivnosti MSP-a u Srbiji. Ova studija pokazuje da poduzeća nemaju sustav koji obezbjeđuje da kupac dobiva kvalitetan proizvod na vrijeme, optimizacija proizvodnje i sredstava su ograničeni, i postoji značajna razlika između zahtjeva radnog mjesta i vještina. Preporuke za poboljšanje aktivnosti uključuju uvođenje sustava praćenja i kontrole kako bi se osigurala blagovremena isporuka i zadovoljstvo kupaca, i uvođenje različitih LM alata.

Ključne riječi: alati; lean proizvodnja; maloserijska proizvodnja; otpad; unaprjeđenje proizvodnje

\section{Introduction}

Lean management represents a set of production management procedures designed for the customer to improve quality and reduce costs and production time [1, 2].

Lean management implementation can provide product differentiation and help the enterprise to operate with less risk in the selected market [3]. Lean management may be observed as a way to reduce costs in a company [4], or as a way to increase customer satisfaction [5]. Lean management also represents a manufacturing philosophy leading to shorter cycle times and elimination of losses.

There are three types of activities in the "flow value" - one of them is activity that creates value, while the other two do not create value but are inseparable from the technology or the production cycle [6]. Only $5 \%$ of all activities add value, $35 \%$ are necessary activities but do not add value, while $60 \%$ of the activities are not necessary and do not add any value [7]. A well-known study of Francis and White [8] shows that $20-50 \%$ of the total manufacturing operation costs represents the materials handling activities. Lean management offers a systematic approach for analyzing and eliminating losses in the manufacturing process leading to an increase in production flexibility [9].

Basic principles of lean management are customer value, value stream, continuous flow, pull, and perfection/continuous improvement [10]. The customer value principle refers to the ability of the enterprise to fulfill customer demands for products and services in time and at the right price. The value stream principle focuses on efficient and standardized work processes, i.e. only the items needed for the next phase or operation are produced.

The key elements for successful implementation of standardization in lean management are operations, time, tools, and accessories $[10,11]$. The principle of continuous flow ensures stable work flows which minimize stops, waste, products of poor quality, and repetitive steps [5]. The pull principle requires the request launch by the customer in order to transfer demand backwards from the final assembly to the raw material warehouses, which generates all the requests as they are needed [12]. The principle of continuous improvement implies constant tendency to satisfy customer needs and improve the manufacturing process without defects [13].

Application of lean management standards has not been investigated before in SMEs in Serbia. However, this practice has been successfully used in neighboring countries, such as Slovenia, Romania and Macedonia. Therefore, we expect that this new approach would generate significant benefits leading to improved business practices in SMEs in Serbia. We envision the following major benefits of lean management implementation: waste reduction, increased efficiency in the workplace, and optimization of the production process.

\section{Lean manufacturing in SMEs}

Lean manufacturing (LM) is more present in large enterprises than in small or medium enterprises [14]. The practice has shown that the methods and instruments of LM are not equally applicable in large and small enterprises [15]. LM can be easiliy applied in enterprises 
which have adopted a quality system and regularly use tools and techniques of quality management. Unfortunately, as the study by Deshmush and Lakhe [16] shows, a majority of small and medium-sized enterprises (SMEs) $(75 \%)$ does not have an ISO certification, which creates obstacles for LM introduction.

According to Lee [17], the following six elements of LM can be easily applied in SMEs: customer focus, top management commitment, quality data and reporting, training, roles of quality departments, and employee involvement. However, the main disadvantages of small enterprises (SEs) in the LM implementation are lack of knowledge and education of employees. This problem can be overcome by linking small and large international or domestic enterprises through knowledge transfer, or with the assistance of the state and international organizations, e.g. MEP (Manufacturing Employment Policy) in USA [18], or UNIDO (United Nations Industrial Development Organization) in Serbia [19]. Either of these approaches facilitates introduction of LM into SMEs.

Lee [17] showed that a $5 \mathrm{~S}$ tool, which focuses on quality, preventive maintenance and employee involvement and requires modest financial investment, is particularly suitable for LM implementation in SMEs. The 5S tool is applied on a micro level, i.e. at the level of the workspace [13]. The implementation of this tool enables employees to create an improved business environment, to advocate more and to solve problems. The 5S tool consists of five elements: sort (classification of objects as waste, rarely used pieces and necessary pieces), set in order (establish a working environment that involves discipline, cleanliness and timely preparation for operation), shine (cleaning, painting and routine maintenance of the working space and environment), standardize (defining and standardizing procedures related to the working process, tasks and activities), and sustain (implement and maintain the $5 \mathrm{~S}$ tool at the institutional and organizational level of the enterprise) [7]. The use of $5 \mathrm{~S}$ tool results in less human effort, space, and capital, shorter processing time, and fewer mistakes, and can be a starting platform for the integrated management system [20].

\section{Serbia in comparison with neighboring countries}

A large number of enterprises located on the territory of the Republic of Serbia belong to a group of small and micro enterprises, which according to a EU classification employ up to 50 workers. Based on the information available in the literature SMEs account for $99.8 \%$ of all firms, of which $95.6 \%$ are micro enterprises (MEs) with less than 10 employees [21].

LM principles are utilized to some extent by SMEs in Serbia and neighboring countries. The extent of utilization is directly proportional to the level of industrialization and strength of interactions of enterprises with key customers.

LM in Romania is implemented in a relatively small number of enterprises through state campaigns promoting significance and benefits of LM. In the case of enterprises which use LM, waste is significantly reduced, productivity is increased, and the use of space is minimized [22]. The $5 \mathrm{~S}$ tool training and use, as well as a focus on teamwork, play a key role in implementing lean concepts (LCs). The participation of LM experts from countries with a tradition (Japan, USA) in implementing LCs is increasing.

The application of LM in Macedonia is focused on the waste reduction, wherever it appears in the organization. The LM strategy is also integrated in R\&D activities and through continuous improvement of production processes within an enterprise [23].

The LM application in the Czech Republic is also more frequent in large enterprises. Implementation of LM tools in SMEs is focused on identification of waste and optimization of the production system and equipment [24].

LM in Croatian SMEs is often implemented through the 5S tool [25]. The use of LM principles was analyzed and several implementation problems were identified: the absence of clearly defined processes, the absence of organizational and social work culture in the enterprise, incorrectly presented concept, poor planning and training of employees [13].

The application of LM in Slovenia can be found in SMEs producing machine parts and related products, as well as those operating in the automotive cluster [26]. In the first case, the benefits of LM are improved environmental protection, simplified production, reduced costs, waste and energy consumption, and improved safety and health of the employees. As the spare part suppliers to the leading French automotive concerns (Renault, Citroen), Slovenian SMEs implement LM tools as an integral part of their operational management.

SMEs in Serbia practice LM less frequently compared to the more developed neighboring countries. LM is mainly introduced in Serbian SMEs through the assistance of international organizations, such as UNIDO, or through vertical integration with larger international customers. Very few sources analyze implementation of LM in Serbian SMEs. However, Djekic et al. [27] demonstrated the benefits of the $5 \mathrm{~S}$ tool implementation in the identification of excess inventory in SMEs at the level of workshops, garages and warehouses of spare parts. Significant changes occurred as several large foreign companies entered Serbian markets through acquisitions or direct foreign investment. For example, the pharmaceutical company Hemofarm, since its acquisition by German company Stada, regularly implements Six Sigma statistical tools and techniques in the manufacturing process [28]. Utilisation of Six Sigma tools and techniques in combination with LM is also increasing in the Serbian food processing industry [29]. Unfortunately, according to the same group of authors, major problems related to the poor knowledge application, lack of properly trained staff, as well as ignorance and incompetence of local officials and experts are hindering efficient LM implementation in SMEs in Serbia and other transition economies [30].

\section{The research methodology}

In this paper we investigated the applicability of the LC to the management of small-scale manufacturing enterprises in Serbia. We specifically analyzed the following elements: production process, supply chain and quality control at the level of the manufacturing process. 
The production process is defined as the transformation process of input units (material and energy) into output units in a form of a finished product. According to Chorpa and Meindl [31], the supply chain is defined as an integrated process involving a large number of distinct economic operators (suppliers, manufacturers, distributors, and retailers) who work together with the aim of providing raw materials, which are transformed into finished products to be delivered to retailers. The quality control is based on the customer attitude about products and customer service.

This research was a part of a broader study investigating various business aspects of manufacturing SMEs in Serbia. Questionnaires were sent electronically to 300 SMEs and the response rate was $25 \%$. According to the official statistics for 2011 (http://webrzs.stat.gov.rs/WebSite/repository/documents/0 0/00/76/17/RD_80_2011_Preduzeca.pdf) the sample size corresponds to $0.5 \%$ of micro and small enterprises operating in the processing industry in Serbia. However, we believe that the total number of relevant micro and small enterprises is significantly lower than the number from the official statistics, since these data include a large but unknown number of enterprises engaged in individual and not in a small-series production, as well as a considerable number of companies that are no longer active due to the ongoing economic crisis in Serbia since 2008. Therefore, the sample size covers a larger percentage of relevant SMEs, which somewhat increases its limited validity. According to data for 2011, SMEs were distributed in two regions: Central Serbia and Vojvodina. About $71 \%$ of SMEs operating in the processing industry were located in Central Serbia, while the remaining $29 \%$ SMEs were from Vojvodina. Our research sample included $74 \%$ of SMEs from Central Serbia and $26 \%$ from Vojvodina, which is close to the official regional distribution. Medium enterprises represented about $63 \%$ of firms, while the other $37 \%$ were small enterprises (SEs). The questionnaires were completed by managers, their deputies, or other company representatives. As Table 1 shows, the research sample included primarily low-tech (LTE) and medium-tech enterprises (MTE) representing a broad range of businesses.

The questions were divided into five categories following in general terms the LM principles. The main objective was to determine divergence between current practices in Serbian SMEs and LM standards and to help in answering the following question:

\section{Is the current way of management compatible with lean concept in small enterprises in Serbia?}

The answers to the questions were initially analyzed using descriptive statistics. Descriptive statistics enabled us to present overall results and determine their statistical significance.

The Chi-Square test was also used to investigate if new product development practices in micro enterprises (MEs) compared to small enterprises (SEs) are different.

The value of $p<0.05$ was taken to indicate statistical significance for rejecting the null hypothesis of homogeneity between ME and SE categories.

Table 1 Manufacturing enterprises in Serbia covered by this research

\begin{tabular}{lc}
\hline \multicolumn{1}{c}{ Business area } & Number of respondents \\
\hline The production of machines and devices, The production of electric and fiber devices & 16 \\
The production of chemicals, chemical products and artificial and synthetic fibers & 16 \\
The production of rubber products and product made from plastic mass & 14 \\
The production of basic metals and standard metal products & 12 \\
Wood processing and products made from wood & 8 \\
The production of food products & 2 \\
The production of textiles and textile products & 2 \\
The production of leather and objects made from leather & 2 \\
Publishing and printing & 2 \\
The production of products made from other non-metal minerals & 2 \\
\hline
\end{tabular}

\section{$5 \quad$ Results and discussion}

First LM principle relates to the ability of enterprises to deliver quality products to the customer on time. Unfortunately, according to Pešić et al. [32], enterprises in Serbia do not attach enough importance to the quality. Our research confirmed insufficient focus on quality and customer satistaction since final products are not always accompanied with necessary documentation. SMEs issued product warranty certificate $(76.3 \%)$, user manual and maintenance $(71.7 \%)$ and the service documentation $(59.5 \%)$, but they did not report any additional activities to ensure customer satisfaction and timely delivery of quality products.

Second LM principle relates to the existence of efficient and standardized work processes in domestic enterprises. According to the questionnaire responses, technical documentation is regularly submitted prior to the beginning of production and a partial standardization of work procedures in the production process is carried out. These standardization procedures are completely fulfilled in SEs, but only at a level of $74 \%(p=0.002)$ and $68 \%(p=0)$ in MEs, respectively. Before the beginning of the manufacturing process, employees receive a clearly defined work order, more often in SEs (86\%) than in MEs $(58 \%)$, which was statistically significant at a 0.035 level. In addition to the work order, the accompanying documents, such as requisition of materials and tools, are always distributed in SEs, but only in $56 \%$ of MEs $(p=0)$. All respondents confirmed that standard procedures were utilized in the storage of materials, semi-finished and finished products, with a special attention given to the control of the product before storage (97\%). Regarding the quality control, more than half of respondents do not 
implement self-control in the workplace $(55 \%)$, but they exercise control of tools, machines and instruments (79\%) and regularly record the irregularities during the production process $(83 \%)$. About $45 \%$ of SMEs conduct preventive maintenance through regular checkups and control of instruments $(71 \%)$ and searching and elimination of weak spots $(29 \%)$. The results of our analysis show that various standardization procedures necessary to improve efficiency in SMEs are not sufficiently implemented, particularly in micro enterprises. As discussed earlier, the application of $5 \mathrm{~S}$ tool at the micro level can significantly improve efficiency in SMEs and also assists in developing selfdiscipline in the work place [33].

Third LM principle is focused on optimizing work flows to reduce frequency of stops, waste and repetitive steps. The responses to the questionnaire show that combined tools $(82 \%)$ and combined machines $(76 \%)$, defined as a combination of standard and special type of equipment, are more often used than conventional tools and machines, which facilitates optimization of the manufacturing process. According to the analysis of the questionnaire, the machines are harmonized during the manufacturing process in $83 \%$ of SEs, but only in $46 \%$ of MEs $(p=0)$. The LM implementation often requires that machines are placed in a shape of letter $U$, which ensures quick change of jobs and allows for unrestricted materials flow [12]. Internal transport is connected with the production and warehouses in $92 \%$ of SEs, but not at all in MEs. Only about half of respondents plan their capacities and define duration of individual work tasks (54\%). Insufficient focus on optimization is also illustrated by the fact that more than two thirds of the enterprises do not perform operational manufacturing preparation $(68 \%)$. SMEs can significantly improve their operations by implementing VSM as a useful LM tool. VSM is a valuable tool for redesigning the productive systems by analyzing the current state and designing an optimized future state for processes that take a product from start all the way to the customer [34].

All interviewed SMEs manufacture products according to customers' specification and documentation. However, SMEs did not report any additional efforts to optimize inventory by using an inventory management tool, such as a Push production system (Just in Time) or inventory analysis linked to the customer orders.

The last LM principle is focused on continuous improvement and development. The need for improvement is particularly important with respect to the education and skills of employees in Serbian SMEs. As pointed by Arandarenko and Bartlett [35], a major gap exists between workers qualifications and skills and the matching job requirements. More than two thirds of responses in our survey $(67 \%)$ indicated at least a partial mismatch between the workers skills and the corresponding job requirements. This problem is partly a result of the inefficient educational system in Serbia, which does not generate profiles according to the needs of manufacturing SMEs. It is not surprising that more than half of responses $(59 \%)$ expressed a need to invest in workers training. The training is in all cases conducted internally with no involvement of external educational centers. The main training fields were quality (64\%), human resources $(61 \%)$, and specialized training $(61 \%)$.
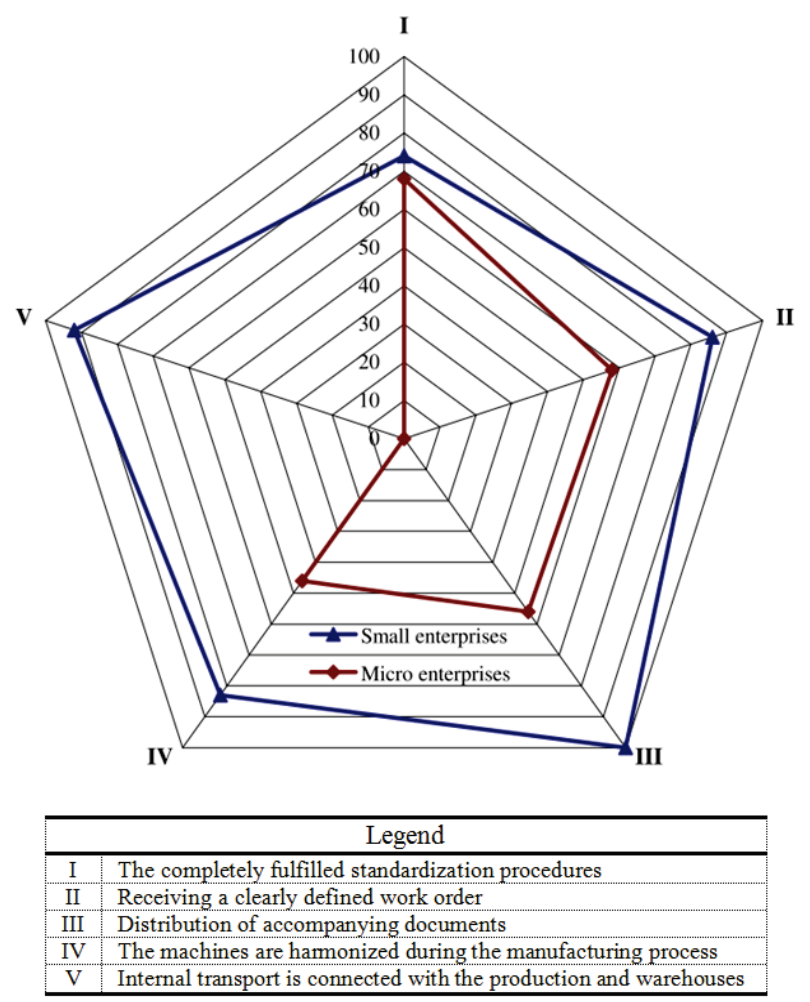

Figure 1 Comparisons between MEs and SEs in Serbia

Fig. 1 shows a comparative overview of the procedures applied according to the LM principles. Only the results that were statistically different in MEs and SEs at a 0.05 level of significance were shown. As one can see, SEs had significant advantages over MEs considering the following procedures: complete fulfilment of the standardization procedures at the time of launch work orders, reception of clearly defined work orders, distribution of accompanying documents, harmonization of machines during the manufacturing process, and connectivity of the internal transport with the production and warehouses.

Our research indicated that no philosophy of continuous improvement on a manufacturing or organizational level was implemented in Serbian SMEs. A quality tool, such as Kaizen, adapted to a Serbian business environment, could help significantly by improving processes, humanizing the workplace, and eliminating business redundancies. According to Imai [36], many small Japanese enterprises achieved significant results by the implementation of the Kaizen program.

As shown above, our research identified number of divergences between current practices in Serbian SMEs and LM standards, so we can conclude that the current way of management is not very compatible with the LC. We propose to bridge this gap by implementing a series of LM tools, as summarized in the next section.

The major limitation of this study is a relatively small sample size with SMEs that covered a broad range of businesses. Therefore, it was not possible to differentiate between business practices of SMEs operating in different business areas. 
Table 2 Analysis of the gaps between current practice and LM principles in Serbian SMEs

\begin{tabular}{|c|c|c|c|}
\hline \multirow[b]{2}{*}{ LM } & \multicolumn{2}{|l|}{ Research - Existing state } & \multirow[b]{2}{*}{ Recomendation } \\
\hline & Elements & $\begin{array}{l}\text { Adv./ } \\
\text { Disa. }\end{array}$ & \\
\hline I & $\begin{array}{l}\text { For each product, enterprises issue supporting documents } \\
\text { (warranty certificate, service list, operating instructions), but do } \\
\text { not follow if the customer is satisfied with the quality or timely } \\
\text { delivery of the product }\end{array}$ & $\mathrm{D}$ & $\begin{array}{l}\text { - Introduce a monitoring and control system to } \\
\text { ensure timely product delivery and customer } \\
\text { satisfaction with the quality. }\end{array}$ \\
\hline \multirow{3}{*}{ II } & Regular delivery of input documentation & A & \multirow{3}{*}{ - Apply 5S tool } \\
\hline & Issue clearly defined work orders & $\mathrm{A}$ & \\
\hline & $\begin{array}{l}\text { Standardization procedures not completely implemented in } \\
\text { micro enterprises }\end{array}$ & $\mathrm{D}$ & \\
\hline \multirow{3}{*}{ III } & $\begin{array}{l}\text { Combined tools and combined machines are used to optimize } \\
\text { the manufacturing process }\end{array}$ & A & \multirow{3}{*}{ - Apply VSM tool } \\
\hline & $\begin{array}{l}\text { Harmonization of machines and internal transport interruptions } \\
\text { not addressed in micro enterprises }\end{array}$ & $\mathrm{D}$ & \\
\hline & Insufficient focus on production optimization & $\mathrm{D}$ & \\
\hline IV & $\begin{array}{l}\text { Production is initiated in accordance with product specification } \\
\text { after a request arrives from customer, but no additional actions } \\
\text { to optimize inventory level }\end{array}$ & A & - Implement an inventory management tool \\
\hline $\mathrm{V}$ & $\begin{array}{l}\text { A partial mismatch between worker skills and the } \\
\text { corresponding job requirements }\end{array}$ & $\mathrm{D}$ & $\begin{array}{l}\text { - Provide additional training of employees to } \\
\text { reduce gap between skills and job requirements } \\
\text { - Introduce a philosophy of continuous } \\
\text { improvement supported at the organizational } \\
\text { and institutional level, such as Kaizen }\end{array}$ \\
\hline
\end{tabular}

\section{Improvement and recommendations}

Based on the analysis presented in this paper, we provide the following suggestions to improve the management of manufacturing SMEs in Serbia. These improvements are aligned with modern business and manufacturing trends and incorporate LM tools, which relate specifically to the inventory, operation management, flow of materials and information, and organizational structure. Tab. 2 summarises individual elements analyzed according to the LM principles and provides the recommendations to bridge the gap between efficient LM and current practice.

\section{Conclusion}

In this paper we analyzed current business practices in small-scale manufacturing enterprises in Serbia in relation to the defined LM principles and provided recommendations necessary to achieve improvement of the business operations. Our research shows that Serbian SMEs do not concentrate on ensuring customer satisfaction, so we recommend introduction of a monitoring and control system to ensure timely product delivery and customer satisfaction with the quality. Standardization procedures are implemented in SEs, but much less in MEs. Further implementation of LM principles in Serbia would enable the waste reduction, reduction of unnecessary activities, efficient use of resources and employees. It is preferred that enterprises actively cooperate with external knowledge centers, universities and institutes. Also, for the quality implementation of LC is important cooperation with international institutions and organizations.

The application of 5S tool should lead to a significant improvement in this area. Results of the questionnaire also demonstrated an insufficient focus on the optimization of production and resources in Serbian SMEs. Significant improvements could be achieved by introducing VSM and inventory management tools. Our research identified a partial mismatch between worker skills and the corresponding job requirements and a lack of focus on continuous improvement. Our recommendations to bridge this gap include additional training of employees and introduction of a philosophy of continuous improvement, such as Kaizen.

\section{Acknowledgement}

This paper is a result of the project TR32008 supported by the Serbian Ministry of Education, Science and Technological Development.

\section{References}

[1] Karlsson, C.; Åhlström, P. Assessing changes towards lean production. // International Journal of Operations \& Production Management. 16, 2(1996), pp. 24-41. https://doi.org/10.1108/01443579610109820

[2] Gracanin D.; Lalic B.; Beker I.; Lalic D.; Buchmeister B. Cost - Time Profile Simulation for Job Shop Scheduling Decisions. // International Journal of Simulation Modelling. 12, 4(2013), pp. 213-224. https://doi.org/10.2507/IJSIMM12(4)1.237

[3] Lewis, M. A. Lean production and sustainable competitive advantage. // International Journal of Operations \& Production Management. 20, 8(2000), pp. 959-978. https://doi.org/10.1108/01443570010332971

[4] Ohno, T. The Toyota Production System: Beyond LargeScale Production, OR: Productivity Press, Portland, 1988.

[5] Womack, J. P.; Jones, D. T. Lean Thinking: Banish Waste and Create Wealth in Your Corporation, NY: Free Press, New York, 2003.

[6] Womack J.; Jones, D. Lean Thinking: Banish Waste and Create Wealth in Your Corporation, Simon \& Schuster, New York, 1996.

[7] Hawkins, L.; Knowledge, P. Fundamental Productivity Improvement Tools and Techniques for SME. Loughborough, Pera Knowledge, (33), 2001. 
[8] Francis, R. L.; White, J. A. Facility layout and location: an analytical approach, Prentice Hall, 1974.

[9] Herzog, N. V.; Tonchia, S. An Instrument for Measuring the Degree of Lean Implementation in Manufacturing. // Strojniški vestnik-Journal of Mechanical Engineering. 60, 12(2014), pp. 797-803. https://doi.org/10.5545/sv-jme.2014.1873

[10] Rother, M.; Shook, J. Learning to see: value stream mapping to add value and eliminate muda, Lean Enterprise Institute, 2003.

[11] Österman, C.; Fundin, A. Exploring approaches how to measure a lean process. // Organizacija. 47, 3(2014), pp. 132-142. https://doi.org/10.2478/orga-2014-0012

[12] Åhlström, P. Sequences in the implementation of lean production. // European Management Journal, 16, 3(1998), pp. 327-334. https://doi.org/10.1016/S0263-2373(98)00009-7

[13] Veža, I.; Gjeldum, N.; Celent, L. Lean manufacturing implementation problems in beverage production systems. // International Journal of Industrial Engineering and Management (IJIEM). 2, 1(2011), pp. 21-26.

[14] Achanga, P.; Shehab, E.; Roy, R.; Nelder, G. Critical success factors for lean implementation within SMEs. // Journal of Manufacturing Technology Management. 17, 4(2006), pp. 460-471. https://doi.org/10.1108/17410380610662889

[15] Matt, D. T.; Rauch, E. Implementation of Lean production in small sized enterprises. // Procedia CIRP. 12(2013), pp. 420-425. https://doi.org/10.1016/j.procir.2013.09.072

[16] Deshmukh, S. V.; Lakhe, R. R. An innovative model of Six Sigma for SMEs: the T-DMAIC model. // International Journal of Six Sigma and Competitive Advantage. 5, 2(2009), pp. 187-203. https://doi.org/10.1504/IJSSCA.2009.025169

[17] Lee, C. Y. TQM in small manufacturers: an exploratory study in China. // International journal of quality \& reliability management. 21, 2(2004), pp. 175-197. https://doi.org/10.1108/02656710410516970

[18] Etemad, H.; Wright, R. W.; Dana, L. P. Symbiotic international business networks: collaboration between small and large firms. // Thunderbird International Business Review. 43, 4(2001), pp. 481-499. https://doi.org/10.1002/tie.1009

[19] Final Report - UNIDO Business partnership programme Serbia. http://www.acserbia.org.rs/pub/article/Final\%20 Report\%20\%28English\%29.pdf (15.04.2015).

[20] Bamber, C. J.; Sharp, J. M.; Hides, M. T. Developing management systems towards integrated manufacturing: a case study perspective. // Integrated Manufacturing Systems. 11, 7(2000), pp. 454-461. https://doi.org/10.1108/09576060010349758

[21] Djordjevic, D.; Cockalo, D.; Sajfert, Z.; Bogetic, S.; Klarin M. Competitive abilities and students' entrepreneurial behaviour: The research results from Serbia. // African Journal of Business Management. 5, 26(2011), pp. 1087810884.

[22] Implementing Lean Management in the Romanian Industry // Lean Business Systems and Beyond Paul Marinescu, Sorin George Toma. Springer US, 2008. pp. 269-276.

[23] Gecevska, V.; Stefanic, N.; Veza, I.; Cus, F. Sustainable Business Solutions through Lean Product lifecycle Management. // Innovation. 2, 4(2012), pp. 8.

[24] Tuček, D.; Dlabač, J. How to build up a Lean Production Systems. // International Journal of Systems Application, engineering \& Development. 6, 3(2012), pp. 242-250.

[25] Erceg, A.; Peterka, S. O.; Dotlić P. Increasing Competitiveness with Lean Thinking-Croatian Case Studies. // 34th Joint Scientific Symposium. / Pforzheim University, 2013, pp. 103-122.
[26] Slavec, A.; Prodan, I. The Slovenian Automotive Cluster. Cluster Development in the Czech Republic and Slovenia, Faculty of Economics, Ljubljana, 2014.

[27] Djekic, I.; Zivanovic, D.; Dragojlovic, S.; Dragovic, R. Lean manufacturing effects in a Serbian confectionery company-Case Study. // Organizacija. 47, 3(2014), pp. 143-152. https://doi.org/10.2478/orga-2014-0013

[28] Hoerl, R. W.; Snee, R. D. Post-financial meltdown: What do the services industries need from us now? // Applied Stochastic Models in Business and Industry. 25, 5(2009), pp. 509-521. https://doi.org/10.1002/asmb.805

[29] Uscebrka, G.; Zikic, D.; Sibalija, T.; Majstorovic, V. Food industry and six sigma methodology. // Optimum Q. 22, 2(2011), pp. 7-12.

[30] Milikić, B.; Janićijević, N.; Petković, M. HRM in transition economies: the case of Serbia. // South East European Journal of Economics and Business. 3, 2(2008), pp. 75-88. https://doi.org/10.2478/v10033-008-0017-5

[31] Chorpa, S.; Meindl P. Supply Chain Management, Pearson Prentice Hall, 2004.

[32] Pešić, M. A.; Milić, V. J.; Stanković, J. Significance of business quality management for increasing competitiveness of Serbian economy. // Serbian Journal of Management. 7, 1(2012), pp. 149-170.

[33] Manotas Duque, D. F.; Rivera Cadavid, L. Lean manufacturing measurement: the relationship between lean activities and lean metrics. // Estudios gerenciales. 23, 105(2007), pp. 69-83. https://doi.org/10.1016/S0123-5923(07)70026-8

[34] Serrano Lasa, I.; Ochoa Laburu, C.; de Castro Vila, R. An evaluation of the value stream mapping tool. // Business Process Management Journal. 14, 1(2008), pp. 39-52. https://doi.org/10.1108/14637150810849391

[35] Arandarenko, M.; Bartlett, W. Labour market and skills in the Western Balkans. Foundation for Advancement of Economics (FREN), Belgrade, 2012.

[36] Imai, M. Kaizen: the key to Japan's competitive success, McGraw Hill, New York, 1986.

\section{Authors' addresses}

\section{Miloš Vorkapić}

University of Belgrade, Institute of Chemistry, Technology and Metallurgy (ICTM) - Center of Microelectronic Technologies Njegoševa 12,11000 Belgrade, Serbia

E-mail: worcky@nanosys.ihtm.bg.ac.rs

Filip Radovanović

University of Belgrade, Institute of Chemistry, Technology and Metallurgy (ICTM) - Center of Microelectronic Technologies Njegoševa 12, 11000 Belgrade, Serbia

E-mail: filip@nanosys.ihtm.bg.ac.rs

\section{Dragan Ćoćkalo}

University of Novi Sad,

Technical faculty "Mihajlo Pupin" Zrenjanin

E-mail: dragan.cockalo@tfzr.rs

\section{Dejan Đordević}

University of Novi Sad,

Technical faculty "Mihajlo Pupin" Zrenjanin Đure Đakovića bb, 23000 Zrenjanin, Serbia

E-mail: dejan.djordjevic@tfzr.rs 